\title{
C L Tパネル二重天井による床衝撃音低減効果に関する検討 STUDY ON FLOOR IMPACT SOUND REDUCTION EFFECT BY DOUBLE CEILING SYSTEM WITH CROSS LAMINATED TIMBER PANELS
}

\author{
田中 学*, 村上剛士**, 笠井祐 輔** \\ Manabu TANAKA, Tsuyoshi MURAKAMI and Yusuke KASAI
}

\begin{abstract}
The purpose of this study is to estimate the improvement effect to floor impact sound insulation performance by double ceiling system with cross laminated timber panels (=CLT panels). Floor impact sound insulation experiments concerning CLT panel double ceiling systems with eight arrangements were carried out in the laboratory. From the results, CLT panel double ceiling system tested in this research was revealed to have more effectiveness to heavy/soft floor impact sound insulation than common gypsum boards double ceiling system. Further, sound pressure in the back cavity and vibration of ceiling panels were also measured and discussed.
\end{abstract}

Keywords : Cross Laminated Timber, Double ceiling system, Floor impact sound, Reduction effect 直交集成板, 二重天井，床衝撃音，低減効果

\section{1.はじめに}

平成 22 年 10 月に「公共建築物等における木材利用の促進に関す る法律 ${ }^{1)} 」$ が施行されるなど, 近年, 建物の木造化や内装部材に木 材を利用する取り組みが活発である。こうした動きは, 国内の人工林 を資源として有効活用寸る目的のほか, 再生可能な循環型社会の実 現を目指したものであり，今後も重要になると予想される。

木質材料を建築部材として活用する取組みの一つとして, 最近で は CLT（Cross Laminated Timber，直交集成板）を木造や鉄骨造 などの建物の床版として使用する試みが幾つか見られる。CLT は, ひき板の各層を繊維方向が互いに直交するよう積層して接着した, 密実な木製パネルである ${ }^{2)}$ 。

CLT 床版の床衝撃音遮断性能に関する既往の測定事例を見ると, 特に重量床衝撃音において, 一般的な枠組壁工法床に比べると遮断 性能が高いものの, 鉄筋コンクリート製の床版（厚 $150 \mathrm{~mm}$ ） と比 較すると 1 ランク程度遮断性能が低い3)。これは CLT の比重が鉄 筋コンクリートの 6 分の 1 程度と軽いことなどが影響していると考 えられる。このため, 今後 CLT 床版を集合住宅などに使用寸るため には, 特に重量床衝撃音に対する遮断性能を向上させることが必要 と考えられる。

CLT 床版の重量床衝撃音遮断性能を高くする方策としては, 床版 自体を厚くする，床版の支持スパンなど平面計画を工夫する，床衝 撃音に低減効果をもつ床仕上げ構造または二重天井を付加する, な どが考えられるが, 本研究では厚 $90 \mathrm{~mm}$ の CLT パネルを二重天井 として使用する方策について試みることとした。
一般的なせっこうボードによる二重天井の場合と比較すると， CLT パネルを二重天井に使用する際の特徴として, 面密度が高いこ と, 曲げ剛性が高いこと, 通常の居室程度であれば CLT パネルの両 端部だけで支持できること, などが挙げられる。また, CLT パネル 二重天井における床衝撃音の伝達系には, せっこうボード二重天井 における吊りボルトを経由する振動伝達系は含まれず，両端支持部 での振動伝達系と天井空気層による音響伝達系のみとなる。

このため, 床衝撃音低減効果に関しては利点も生じると考えられ る一方, 既往の研究に多く見られるせっこうボード二重天井の測定 事例や諸要因の検討事例などの知見例えば 4) 6)などはそのまま適用で きない可能性があり，新たな検討が必要となる。

そこで本研究では, 一般的な厚 $210 \mathrm{~mm}$ の CLT パネル床版を基本 ベースとして, 厚 $90 \mathrm{~mm}$ の CLT パネル二重天井を付加した場合の 床衝撃音レベルの変化を実験室において測定し, CLT パネル二重天 井による床衝撃音低減効果を把握する。また, 天井空気層による音 響伝達系に係る要因に着目した複数の試験体仕様についても測定を 行い，これら要因による影響について検討を加える。

\section{2. 実験内容}

\section{1 実験室}

実験は図 1 に示す一般財団法人日本建築総合試験所の残響室で 実施した。この残響室は鉄筋コンクリート造で上下 2 室が連接して おり，残響室間には $2500 \mathrm{~mm} \times 4000 \mathrm{~mm}$ の開口が設けられている。
* (一財) 日本建築総合試験所 修士 (工学)

**（一財）日本建築総合試験所
General Building Research Corporation of Japan, M. Eng.

General Building Research Corporation of Japan 


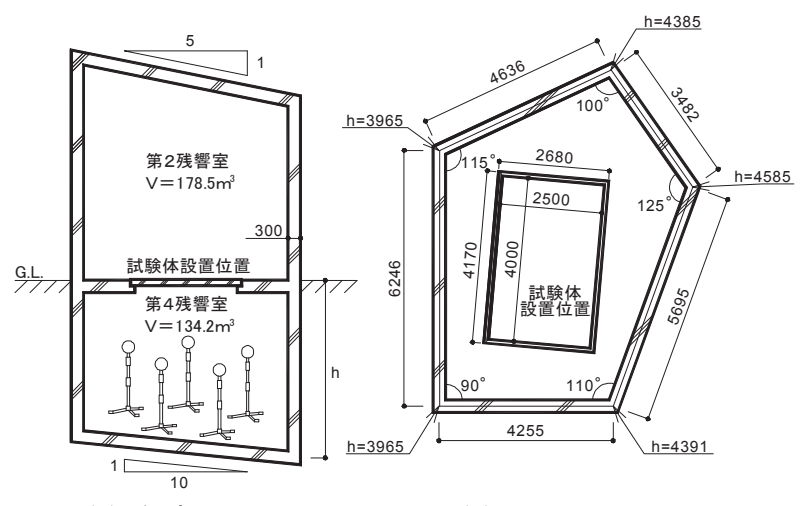

(1) 鉛直断面図
(2) 平面図

図 1 実験室の概要

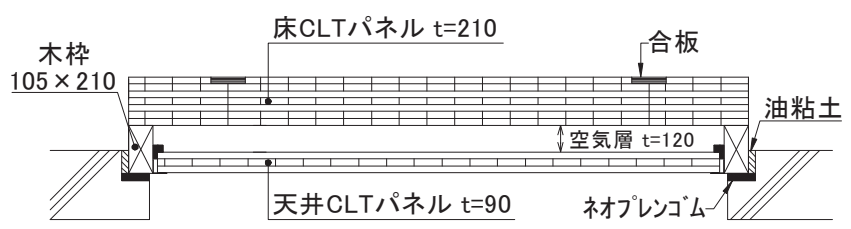

図 2 試験体の鉛直断面図（試験体 No. 1a）

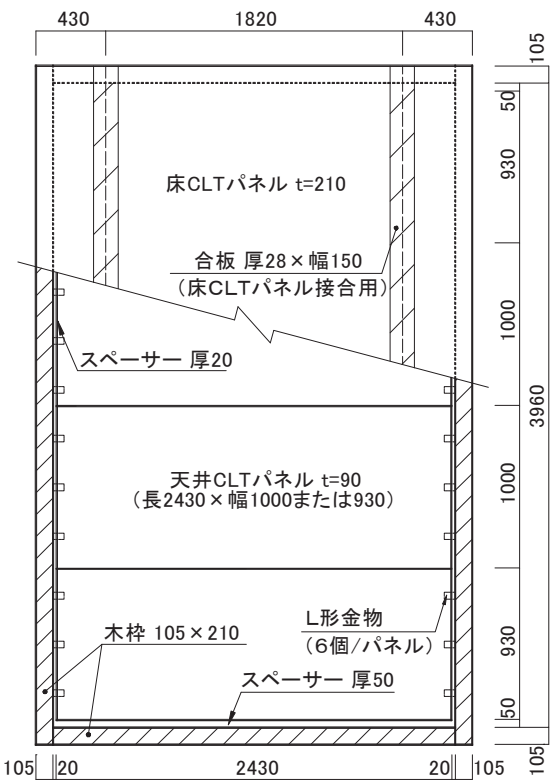

図 3 試験体の平面図（試験体 No. 1a）

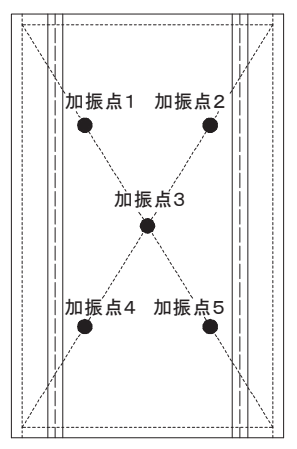

（1）床上 (加振点)

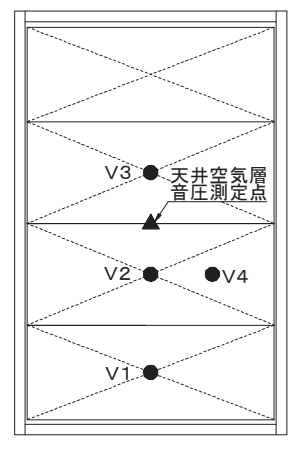

（2）天井(振動・音圧)
図 4 加振点および天井振動 - 空気層音圧測定点の位置図
[寸法単位 : mm]
(1) 試験体 No. 0

グラスウール $\left(24 \mathrm{~kg} / \mathrm{m}^{3}, \mathrm{t}=50\right)$

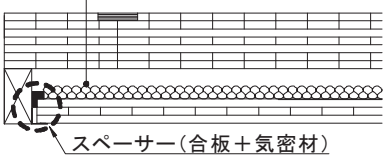

(3) 試験体 No. 1b

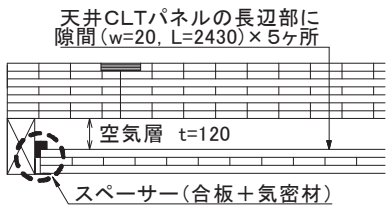

(5) 試験体 No. $2 b$

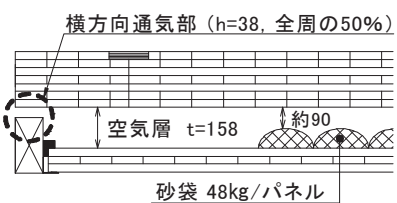

(7) 試験体 No. 3b

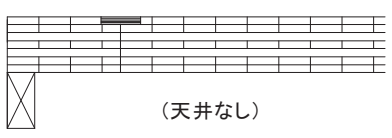

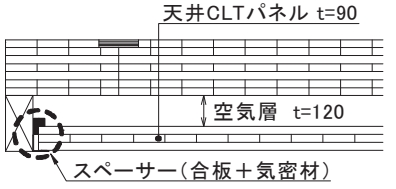

(2) 試験体 No. 1a

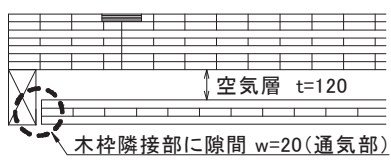

(4) 試験体 No. 2a

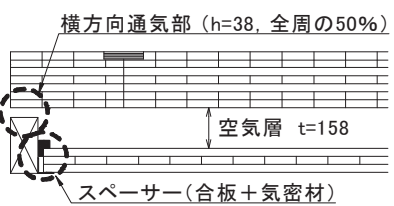

(6) 試験体 No. 3a

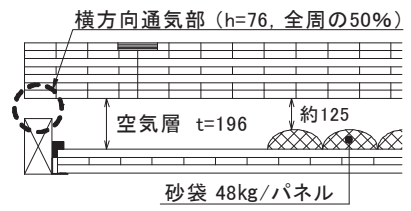

（8）試験体 No. 3c
図 5 試験体の仕様（端部鉛直断面図）

表 1 試験体 (全 8 体)の仕様一覧

\begin{tabular}{c|l}
\hline No. & \multicolumn{1}{|c}{ 試験体の仕様 } \\
\hline 0 & 天井なし \\
\hline $1 \mathrm{a}$ & 天井あり, 通気なし \\
\hline $1 \mathrm{~b}$ & 天井あり, 通気なし, 吸音材挿入 \\
\hline $2 \mathrm{a}$ & 天井あり, 下方向通気 (天井と木枠の隣接部) \\
\hline $2 \mathrm{~b}$ & 天井あり, 下方向通気 (天井 CLT パネル長辺の目地部) \\
\hline $3 \mathrm{a}$ & 天井あり, 横方向通気 \\
\hline $3 \mathrm{~b}$ & 天井あり, 横方向通気, 砂袋積載 \\
\hline $3 \mathrm{c}$ & 天井あり, 横方向通気 (2倍), 砂袋積載 \\
\hline
\end{tabular}

各試験体は順次この開口に設置して測定に供した。なお，実験室お よび試験体設置の条件は ISO 10140-3：2010 に準じた。

\section{2 試験体の概要}

本研究では先ず, 天井無しの仕様として厚 $210 \mathrm{~mm}$ の CLT パネル による床版を作成し，これを試験体 No.0 とした。その他の試験体 は試験体 No.0 の下側に CLT パネル厚 $90 \mathrm{~mm}$ (面密度 $36 \mathrm{~kg} / \mathrm{m}^{2}$ ) に よる二重天井を付加した仕様である。各試験体の仕様を図 2～5 お よび表 1 に示す。

天井として CLT パネルを取り付けた仕様を試験体 No.1a, その中 に吸音材として密度 $24 \mathrm{~kg} / \mathrm{m}^{3}$ ・厚 $50 \mathrm{~mm}$ のグラスウールを挿入した 仕様を試験体 No.1b とした。天井 CLT パネルは図 3 に示すように 短辺部分を $\mathrm{L}$ 形金物（6 個/ハネル）に載せる方法で支持した。

試験体 No.2a 3c は, 乾式二重床における重量床衝撃音の性能向 上対策7)を参考に，天井の周囲に通気の隙間を設けた仕様である。 
このうち, 試験体 No.2a および試験体 No.2b は図 5(4)・(5)に示すよ うに，下室方向に通気を設けた仕様である。なお，試験体 No.2a は 天井四周の木枠との隣接部全辺（長さ $13 \mathrm{~m} ）$ に隙間を設けたもので ある。試験体 No. $2 \mathrm{~b}$ は天井四周の木枠との隣接部部分は密閉に戻し, 天井 CLT パネル 4 枚の長辺部 5 箇所 (長さ $2.43 \mathrm{~m} \times 5$ 箇所) の目地 部に隙間を設けたものである。隙間の幅はいずれも $20 \mathrm{~mm}$ とした。

試験体 No.3a〜 3c は図 5(6)〜(8)のように, 四周木枠の上部に隙間 を開けて横方向に通気を設け，受音室側は気密にした仕様である。 また試験体 No.3b・3c では, 天井 CLT パネルの中央部分 (天井 CLT パネルの面積の約 $1 / 6$ に相当する部分) に天井 CLT パネルの振動抑 制を目的に砂袋（48kg/パネル）を設置した仕様である。

\section{3 測定内容}

各仕様の CLT パネル二重天井による床衝撃音低減効果を調べる ため, 床衝撃音遮断性能の測定を行った。衝撃源には, JIS A 1418-1 に規定される標準軽量衝撃源（以下，タッピングマシンと呼ぶ）, および JIS A 1418-2 に規定される衝撃力特性(1)の標準重量衝撃源 （以下, タイヤ衝撃源と呼ぶ）を使用し, 加振点は図 4(1)に示した 5 点とした。計測用マイクロホンは 5 本とし, 受音室の床上 1500 〜 1900mm の高さに分布させて設置した。計測用マイクロホンから の出力信号を多チャンネル分析器 (小野測器 DS-2000) に接続して, 音圧レベルを分析した。

軽量衝撃については中心周波数 $63 \sim 2000 \mathrm{~Hz}$ の $1 / 1$ オクターブバ ンド毎の時間平均音圧レベルおよび残響時間を測定し，規準化床衝 撃音レベルを算出した。また, 重量衝撃に対する測定量は, 中心周 波数 $63 \sim 500 \mathrm{~Hz}$ の $1 / 1$ オクターブバンド毎の時間重夕特性 $\mathrm{F}$ での 音圧レベル最大值とした。

試験体 No.1a および試験体 No.2a〜No.3c については, 重量衝撃 に対する天井 CLT パネルの振動性状を把握するため, 図 4(2)に示 す天井 CLT パネル表面の 4 点（V1〜V4）に振動加速度ピックアッ プを取付け, 振動加速度の時間応答を測定した。また, 天井空気層 の空気音圧変動を把握するため, 空気層内に騒音計のマイクロホン を設置し，音圧の時間応答を測定した。

なお, 試験体 No.3a〜 3c では, 重量床衝撃音遮断性能の検討を主 目的としており, また垂直方向の基本的な断面構成は試験体 No.1a と同じであることから，軽量床衝撃音レベルの測定を省略した。

\section{3. 床衝撃音レベルの測定結果と考察}

各試験体の床衝撃音レベルの測定結果を図 6〜9 亿示す。

以下では, 試験体 No.1a（または試験体 No.0）に対する試験体仕 様の変化要因毎に, 測定結果の比較と考察を示寸。

\section{1 C L T パネル二重天井の有無による差異}

CLT パネル床構造のみの試験体 No.0 と, その下部に CLT パネル 二重天井を付加した試験体 No.1a の床衝撃音レベルを図 6 に示す。 CLT パネル二重天井を付加すると, 重量衝撃については, 125〜 $500 \mathrm{~Hz}$ 帯域では $2 \sim 7 \mathrm{~dB}$ 程度の低減効果が見られ, $63 \mathrm{~Hz}$ 帯域では ほぼ変化が無く同じ床衝撃音レベルである。せっこうボード二重天井 の測定例4) では $63 \mathrm{~Hz}$ 帯域で 3 6dB 程度の増幅効果が現れている が，CLT パネル二重天井ではこうした増幅の傾向は見られない。

空気層を持つ二重天井における床衝撃音の増幅傾向は, 天井面材 を質量, 天井空気層をばねとする振動系の共振の影響と考えられて

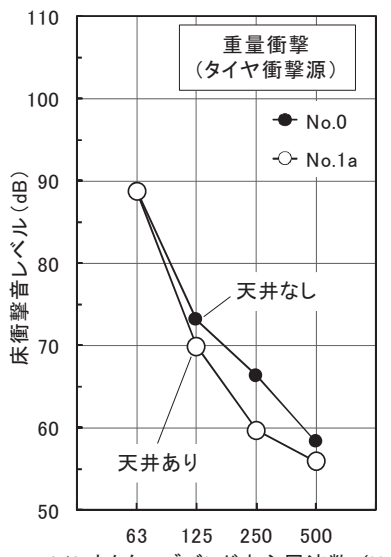

$1 / 1$ オクターブバンド中心周波数 $(\mathrm{Hz})$
（1）重量床衝撃音

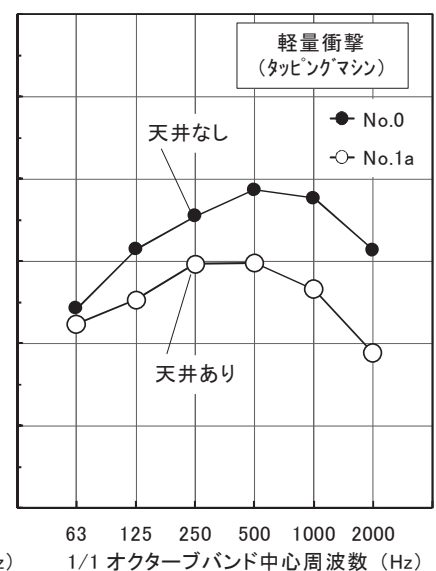

（2）軽量床衝撃音
図 6 CLTパネル二重天井の有無による床衝撃音レベルの差異

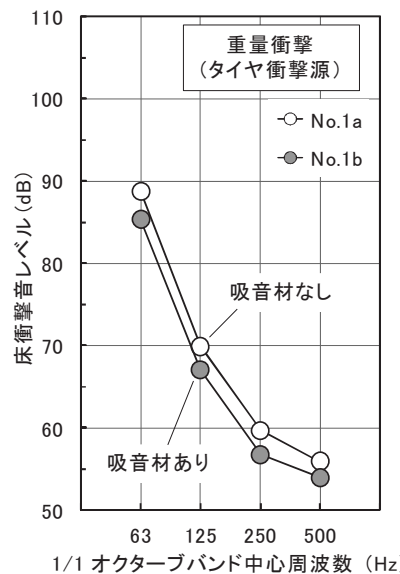

（1）重量床衝撃音

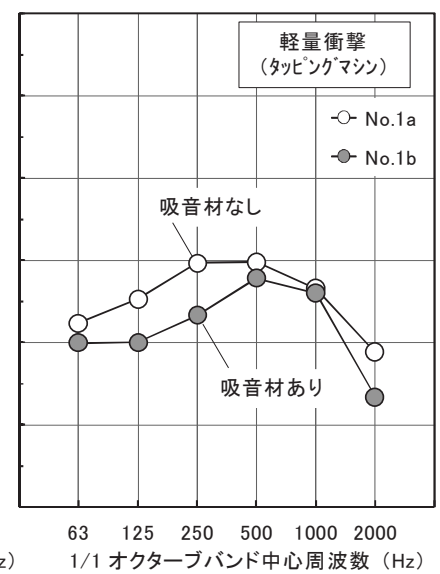

(2) 軽量床衝撃音
図 7 吸音材有無による床衝撃音レベルの差異

おり ${ }^{4)}$ ，その共振周波数 $f_{0}[\mathrm{~Hz}]$ は式(1)により概算できる。

$$
f_{0}=\frac{1}{2 \pi} \sqrt{\frac{K}{m \cdot h}}
$$

ただし， $K$ : 空気の体積弾性率 $\left[=1.4 \times 10^{5} \mathrm{~N} / \mathrm{m}^{2}\right], m$ : 天井面材 の面密度 $\left[\mathrm{kg} / \mathrm{m}^{2}\right], h:$ 天井空気層厚 $[\mathrm{m}]$, である。

ボード厚 $9.5 \mathrm{~mm}$ ・空気層厚 100 200mm 前後の仕様のせっこう ボード二重天井の場合, (1)式による共振周波数は $63 \mathrm{~Hz}$ 帯域に入る。 一方，パネル厚 $90 \mathrm{~mm} ・$ 空気層厚 $120 \mathrm{~mm} の \mathrm{CLT}$ パネル二重天井 について同様に概算した共振周波数は約 $29 \mathrm{~Hz}$ となり， $63 \mathrm{~Hz}$ 帯域 より低い帯域に共振周波数を持つと考えられる。このため, $63 \mathrm{~Hz}$ 帯域では増幅傾向が見られなかったものと推測される。なお，(1)式 より, 厚 $90 \mathrm{~mm}$ の CLT パネルを用いた二重天井では, 天井空気層 厚が約 $50 \mathrm{~mm}$ 以上の場合に共振周波数が $63 \mathrm{~Hz}$ 帯域より低い周波数 となり，床衝撃音はほぼ同様の傾向を示すと予測される。

軽量衝撃については $125 \sim 2000 \mathrm{~Hz}$ 帯域で 6 $13 \mathrm{~dB}$ 程度の低減効 果が現れている。せっこうボード天井の測定例4) では $125 \sim 500 \mathrm{~Hz}$ 帯域で $0 \sim 10 \mathrm{~dB}$ 程度の低減効果であり, ほぼ同等以上の性能である。 
以上より, CLT パネル二重天井(パネル厚 $90 \mathrm{~mm}$ •空気層厚 $120 \mathrm{~mm}$ ) を付加すると, 重量衝撃に対しては天井無しの場合とほぼ同等の床 衝撃音遮断性能となり, 軽量衝撃に対しては床衝撃音低減効果が生

じるといえる。

\section{2 吸音材の有無による差異}

CLT パネル二重天井の上部の空気層に吸音材を挿入した試験体 No.1b と吸音材が無い試験体 No.1a の床衝撃音レベルを図 7 に示す。 吸音材を挿入すると重量衝撃では $63 \sim 500 \mathrm{~Hz}$ の各帯域とも床衝撃 音レベルが $2 \mathrm{~dB}$ 程度小さくなる。軽量衝撃では $125 \mathrm{~Hz}, 250 \mathrm{~Hz}$, $2000 \mathrm{~Hz}$ 帯域では床衝撃音が 5 6dB 程度小さくなるが，500～ $1000 \mathrm{~Hz}$ 帯域では 1 2dB 程度の変化にとどまる。吸音材挿入によ る低減効果が小さい周波数帯域については, 床 CLT パネルから音響 放射される空気伝搬音以外の影響が大きかったためと推測される。

\section{3 天井空気層の下方向への通気による差異}

天井 CLT パネルの下方向に通気を設けた試験体 No.2a・No.2b と, 空気層に通気が無い試験体 No.1a の床衝撃音レベルを図 8 に示寸。 天井四周に通気部分を設けると空気層に通気の無い場合よりも重量 床衝撃音が大きくなる。これは, 乾式二重床の場合に四周に通気部 分を設けると重量床衝撃音が小さくなる7)こととは逆の傾向である。 また, 天井 CLT パネルの目地部に隙間を開け, 天井空気層に対して 約 $1 \mathrm{~m}$ の短い間隔で通気部分を設けた場合（試験体 No.2b）にも, 重量床衝撃音はほぼ同じ程度に大きくなる。

軽量衝撃についても, 試験体 No.2a・No.2b ともに, 通気の無い 場合よりも床衝撃音レベルが大きくなり, 四周に隙間がある試験体 No.2a のほうがより大きい。試験体 No.2a では天井と四周木枠との 隅角部に隙間があるため隙間部分からの音響透過が大きくなるため と推察される。また, $2000 \mathrm{~Hz}$ 帯域では試験体 No.2a・No.2b とも に通気無しとの差が大きいが, これは天井 CLT パネルの厚さに応じ た隙間部分を開管とする共鳴透過の影響と考えられる。

以上より, CLT パネル二重天井（厚 $90 \mathrm{~mm}$ ・空気層厚 $120 \mathrm{~mm}$ ) において天井空気層に下階（受音室）方向の通気を設けると，重量 衝撃・軽量衝撃いずれも床衝撃音を大きくする効果が生じるため, 注意が必要である。

\section{4 天井空気層の横方向への通気部の設置による差異}

天井空気層の横方向に通気を設けた試験体 No.3a と, 空気層に通 気が無い試験体 No.1aの重量床衝撃音レベルを図 9(1)に示す。なお, 試験体 No.3a では通気部の設置に伴い, 天井空気層が厚 $158 \mathrm{~mm}$ に なり，試験体 No.1 の場合よりも $38 \mathrm{~mm}$ 厚くなっている。

横方向に通気を設けた試験体No.3aでは試験体No.1aよりも重量 床衝撃音が小さくなる。その変化量は $63 \mathrm{~Hz}$ 帯域で約 $5 \mathrm{~dB}, 125$ $500 \mathrm{~Hz}$ 帯域で約 3〜6dB と, 変化の幅は大きい。したがって, CLT パネル二重天井 (厚 $90 \mathrm{~mm}$ ) の No.1a の仕様に対して, 天井空気層 の横方向に通気を設けるNo.3aの仕様にすると, 重量衝撃に対する 床衝撃音遮断性能は 1 ランク程度向上すると考えられる。

なお，試験体 No.3a の天井空気層厚 $158 \mathrm{~mm}$ の条件で CLT パネ ル二重天井の共振周波数を式(1)から求めると約 $25 \mathrm{~Hz}$ と算出され, 試験体 No.1 からの共振周波数の変化による影響は小さいと考えら れる。一方, 天井空気層の容積は試験体 No.1 に対して約 $32 \%$ 増加 しており,タイヤ衝撃源による加振時の CLT 床パネルの変位による 天井空気層の空気圧縮を緩和する効果も含まれると推察される。

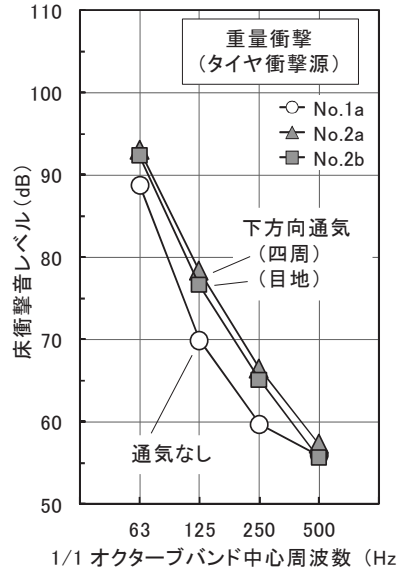

（1）重量床衝撃音

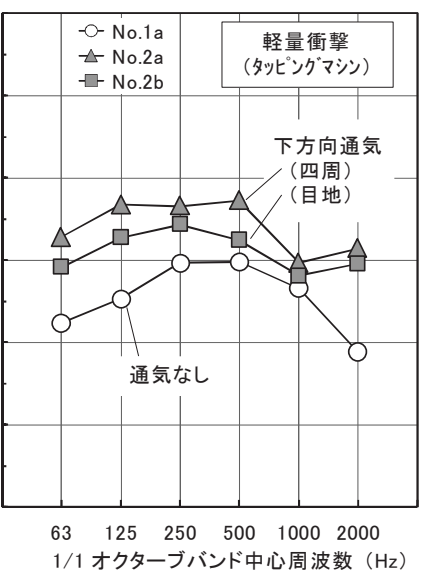

（2）軽量床衝撃音
図 8 下方向通気の有無による床衝撃音レベルの差異

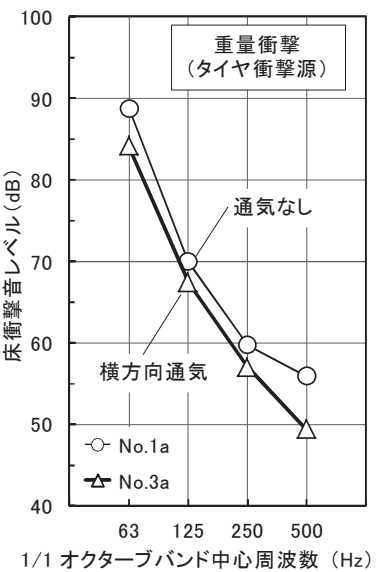

（1）横方向の通気部の有無に よる差異

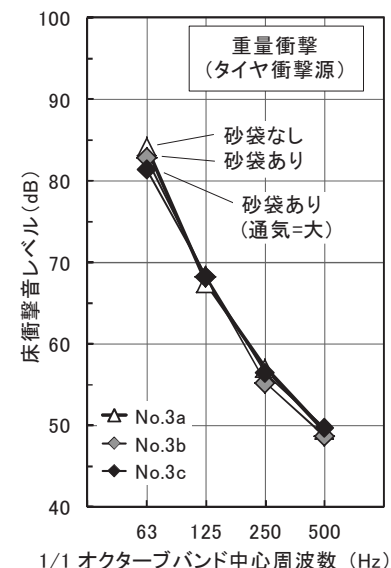

（2）砂袋の有無および通気部 の大小による差異
図 9 重量床衝撃音レベルの差異

\section{5 砂袋の有無および通気部の大小による差異}

通気を横方向にとり砂袋を設置した試験体 No.3b，砂袋を設置し 通気を 2 倍とした試験体 No.3c，および砂袋の無い試験体 No.3aの 重量床衝撃音レベルを図 $9(2)$ に示す。 Lr 等級の性能決定上重要とな る $63 \mathrm{~Hz}$ 帯域の重量床衝撃音は砂袋を設置することで約 $1.5 \mathrm{~dB}$ 小さ くなり，通気を 2 倍（通気幅を 2 倍）にすることでさらに約 $1.5 \mathrm{~dB}$ 小さくなる。なお， $125 \sim 500 \mathrm{~Hz}$ 帯域での試験体 No.3a からの変化 幅は最大でも約 $1.5 \mathrm{~dB}$ であった。

試験体 No.3b・No.3c について, 砂袋の荷重を均等分布に置き換 えて CLT パネル二重天井の共振周波数を式(1)から求めると, それ ぞれ約 $20 \mathrm{~Hz}$ ・約 $18 \mathrm{~Hz}$ と算出され, 試験体 No.3a の約 $25 \mathrm{~Hz}$ より もやや低い周波数である。また, 試験体 No.3c では天井空気層の厚 さは $196 \mathrm{~mm}$ に増加しており, 天井空気層の容積の増加にともない 空気圧縮を緩和寸る効果も含まれていると推察される。さらに試験 体 No.3c では，通気部の開口部の幅が試験体 No.3a・No.3b よりも 大きくなったことで通気時の抵抗は小さくなり，通気部の設置によ る低減効果を大きくする寄与も生じていると考えられる。 

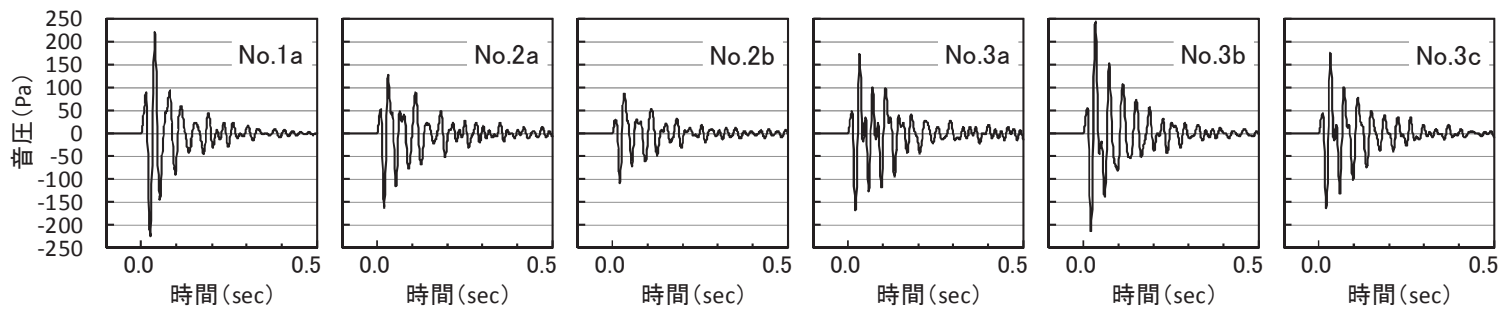

図 10 天井空気層音圧の時間応答波形の測定結果（加振点 3)
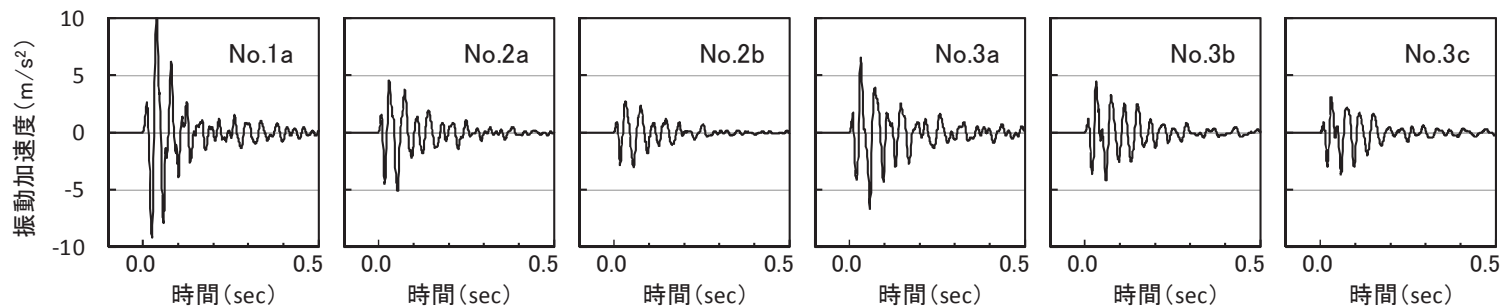

図 11 天井パネルの振動加速度時間応答波形の測定結果（加振点 3, 振動測定点 V2）

表 2 各試験体による試験体 No. 0 からの L 数の変化量

\begin{tabular}{c|c|c|c|c|c|c|c}
\hline 試験体 & No.1a & No.1b & No.2a & No.2b & No.3a & No.3b & No.3c \\
\hline 重量衝撃 & \pm 0 & -4 & +4 & +3 & -5 & -6 & -8 \\
\hline 軽量衝撃 & -11 & -12 & -3 & -7 & - & - & - \\
\hline
\end{tabular}

\section{6 各天井仕様による床衝撃音遮断性能の変化}

各試験体の床衝撃音レベル測定結果について, JIS A 1419-2:2000 附属書 1 の $\mathrm{Lr}$ 等級に準じて遮音等級を $1 \mathrm{~dB}$ 単位で求め（ここでは L 数と呼ぶ), 天井の無い試験体 No.0からの変化量を求めた結果を 表 2 に示寸。同表中, 負の数值は試験体 No.0 に対して床衝撃音が 小さくなり，床衝撃音低減効果があることを表している。

吸音材を挿入した CLT 二重天井 (No.1b), あるいは天井空気層 の横方向に通気を設けて砂袋を設置した CLT二重天井(No.3a〜 3c) を付加することで, 重量床衝撃音に対する L 数は 4 ～ 8 ポイント低 下し低減効果が高いことが判る。また, 軽量床衝撃音に対しても CLT 天井を付加すると L 数を最大 11 ～12 ポイント低下させる効果 があることが判る。ただし, 天井空気層の下方向に通気を設けると 重量床衝撃音に対して L 数が大きくなり，注意が必要である。

\section{4. 天井の空気層音圧・振動加速度の測定結果と考察}

天井空気層に通気を設けた試験体 No.2a～3c における重量床衝撃 音レベルの差異は, 主に天井空気層の空気圧縮を伴う衝撃力の伝搬 が影響していると推測される。このため, 天井空気層の音圧と天井 CLT パネルの振動応答を測定し，その傾向について検討した。

試験体 No.1a および No.2a〜No.3c における天井空気層の音圧と 天井 CLT パネルの振動加速度の測定結果を図 10１4 に示す。

図 10〜11 は加振点 3 (CLT パネル床構造の中央) を加振した時 の時間応答波形の例である。図 $12 \sim 13$ は各加振点を加振した時の 天井空気層音圧測定点・振動測定点 $\mathrm{V} 1 \sim \mathrm{V} 4$ の各周波数帯域成分の 時間応答波形に対して時間重多特性 $\mathrm{F}$ の最大值を求め，全加振点 全測定点について算術平均したデータである。図 14 はオールパス とした時間波形に対する時間重み特性 $\mathrm{F}$ の最大值を求め, 同様に全

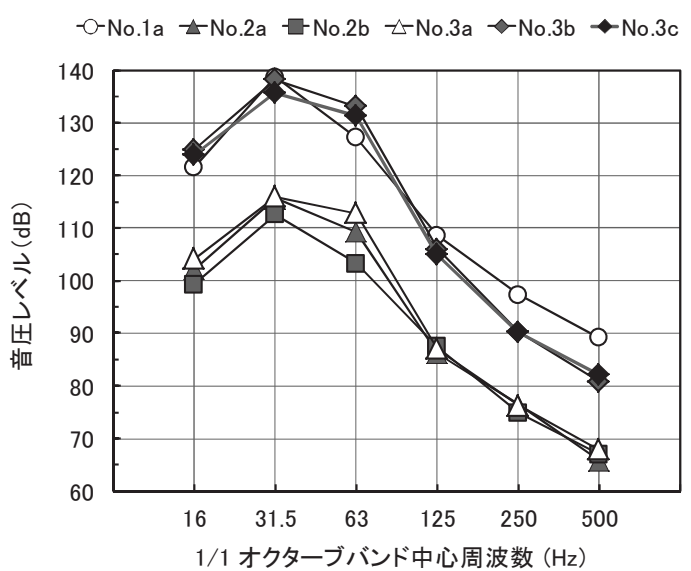

図 12 天井空気層音圧の周波数分析結果

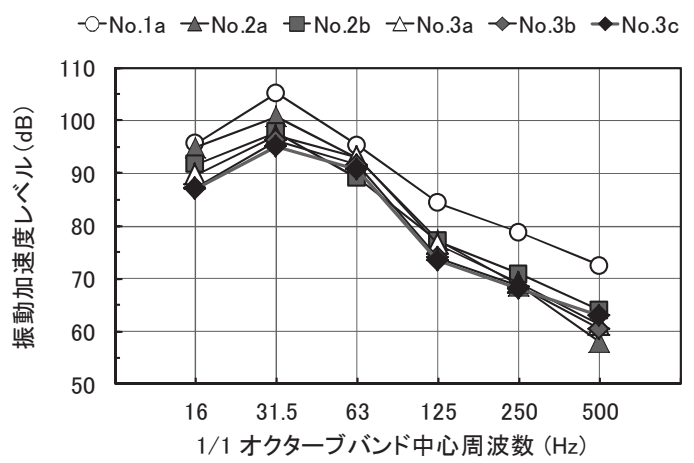

図 13 天井振動加速度の周波数分析結果

加振点・全測定点について算術平均し, 試験体仕様による天井空気 層音圧と天井パネル振動加速度の変化をまとめたものである。

天井空気層音圧の時間応答波形（図 10）および天井パネルの振動 加速度時間応答波形（図 11）を見ると，どの試験体も加振後 0.1 秒 以内に音圧・振動加速度ともにピークが生じ，その後は急激に減衰 する。天井空気層の音圧および天井パネルの振動加速度のピーク值 は最大 $2.5 \sim 3$ 倍の差異があり，試験体による差異は顕著である。 


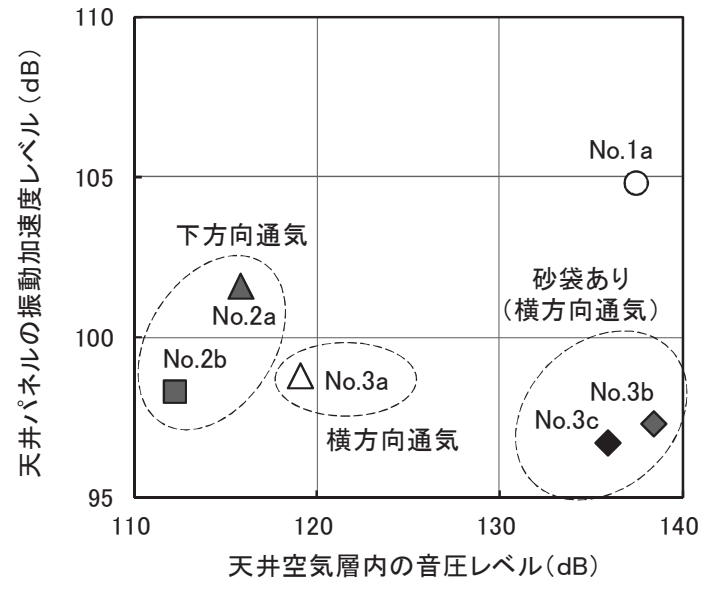

図 14 各試験体の天井空気層音圧と天井振動加速度

天井空気層音圧の周波数分析結果（図 12）を見ると, 各試験体と も $31.5 \mathrm{~Hz}$ 帯域にピークを有する。上部構造の床 CLT パネル部分に ついて振動応答を実測すると 1 次固有振動数が約 $29 \mathrm{~Hz}$ であった8)。 天井空気層音圧のピークの帯域と一致しており, 床 CLT パネルの振 動特性の影響を受けていると考えられる。なお, 各試験体の CLT 二重天井について(1)式から求めた共振周波数は前述の通り約 18〜 $29 \mathrm{~Hz}$ であり, $31.5 \mathrm{~Hz}$ 帯域又は $16 \mathrm{~Hz}$ 帯域に含まれている。しかし, 天井空気層の音圧について $16 \mathrm{~Hz}$ 帯域にピークを持つ試験体は見ら れないことから, 天井空気層音圧に対しては床 CLT パネルの振動特 性の影響のほうが支配的であったものと考えられる。

図 12 を見ると, 通気の無い試験体 No.1に対し, 下方向に通気を 設けた試験体 No.2a・No.2b および横方向に通気を設けた試験体 No.3a は天井空気層の音圧レベルが全ての周波数帯域で 14〜26dB 程度小さい。砂袋を設置した試験体 No.3b・No.3c は通気があるも のの天井空気層の音圧レベルの大きさの程度は試験体 No.1 と類似 している。

また天井 CLT パネルの振動の周波数分析結果 (図 13) を見ると, 天井 CLT パネルの振動加速度レベルは試験体により各周波数帯域 において 6 15dB 程度の差異が見られる。振動加速度レベルのピー クの帯域は全ての試験体で $31.5 \mathrm{~Hz}$ 帯域である。これは床下空気層 音圧のピークの帯域と同じであり, 天井 CLT パネルの振動特性は床 下空気層音圧の周波数特性の影響を受けていると推察される。

ただし, 図 12 と図 13 の周波数特性を詳細に比較すると, 例えば 各試験体における $31.5 \mathrm{~Hz}$ 帯域と $63 \mathrm{~Hz}$ 帯域とのレベル差の大小関 係は音圧と振動加速度とで必ずしも一致せず, 天井 CLT パネルの振 動特性が隙間（通気部）の有無・砂袋の有無・背後空気層の厚さに よっても異なるため, その影響も受けていると推察される。このた め, 天井空気層音圧と天井振動加速度のオールパス波形最大值の関 係を図 14 にまとめ, 試験体仕様による傾向に考察を加えた。

通気の無い試験体 No.1a に対して, 下方向に通気を設けた試験体 No. $2 \mathrm{a} \cdot \mathrm{No} .2 \mathrm{~b}$ では, 天井空気層の音圧の最大值は小さくなり, 天 井パネルの振動加速度の最大值も小さくなっている。これは通気を 設けることで天井空気層が密閉から解放され, 床 CLT パネルが加振 されて振動しても空気層の圧力が高くならないためと推察される。

図 8(1)において試験体 No.2a・2b は試験体 No.1a より重量床衝
撃音レベルは大きくなっているが，これは，圧縮された天井内の空 気が通気部分を経由して受音室（下階）側に放射され，その影響で 受音室における重量床衝撃音レベルが上昇したと考えられる。

なお, 試験体 No.2a よりも試験体 No.2b のほうが天井空気層音 圧・天井振動加速度ともに小さいが，これはタイヤ衝撃源による加 振により床パネルが下方向に変位する際, 天井空気層に対して約 $1 \mathrm{~m}$ の短い間隔で通気部分を設ける場合のほうが天井空気層内の空 気は通気しやすく天井空気層内の空気圧の上昇が抑制されたため, と考えられる。

次に, 横方向に通気させた試験体 No.3a では, 試験体 No.1a に対 して天井空気層音圧の最大值は約 $20 \mathrm{~dB}$ 小さくなり, 天井パネルの 振動の最大值も約 $6 \mathrm{~dB}$ 小さくなっている。試験体 No.2a・No.2b と 同様に, 天井空気層が密閉から解放され, 床 CLT パネルが加振され て振動しても空気層の圧力が試験体 No.1a に比べて高くならないた めと推察される。

砂袋を設置した試験体 No.3b・No.3c では, 試験体 No.1の場合と 天井空気層音圧はほとんど変わらない一方, 天井パネルの振動加速 度は約 8dB 小さくなっている。これは, 砂袋の設置より試験体 No3a に比べて天井パネルの面密度が増加したため圧縮空気に対する変位 が小さくなり相互作用として天井空気層音圧が上昇しているためと 考えられる。なお, 試験体 No.3b と No.3c を比較すると, 天井空気 層の音圧・天井パネルの振動加速度レベルともに, 試験体 $3 \mathrm{c}$ のほう がやや小さくなっており, 通気部を 2 倍にする試験体 No.3c の仕様 では重量床衝撃音レベルがやや小さくなる傾向と一致している。

\section{5. まとめ}

CLT 床版の床衝撃音遮断性能を向上させる目的で, CLT 床版の 下部に厚 $90 \mathrm{~mm}$ の CLT パネルによる二重天井を設置した試験体を 作成し, 実験室において吸音材の有無・天井空気層の通気の有無・ 砂袋設置の有無などの条件を変えて床衝撃音レベルの測定を行った。 その結果, 以下の点が明らかになった。

・天井空気層を密閉とした CLT パネル二重天井 (パネル厚 $90 \mathrm{~mm}$ ・ 空気層厚 $120 \mathrm{~mm}$ ）を付加しても，せっこうボード二重天井の場 合のような $63 \mathrm{~Hz}$ 帯域における重量床衝撃音を増幅する効果は生 じず，重量床衝撃音遮断性能は天井無しの場合と同じ水準を維持 する。一方, 軽量床衝撃音に対しては $10 \mathrm{~dB}$ 程度の低減効果が見 られ, 床衝撃音低減対策として有効である。

・この CLT パネル二重天井について, 天井空気層を密閉とせずに, 下方向（受音室側）に通気部分を設けた場合，天井空気層の音圧 レベルの上昇と天井 CLT パネルの振動を抑制する効果はあるが, 天井空気層を密閉とした場合に比べて受音室では重量・軽量床衝 撃音ともに大きくなる傾向が見られ, 床衝撃音低減対策としては 適切でない。これは, 通気部分から天井空気層の圧縮空気が受音 室に放射されること, および，通気部分により天井パネル全体の 空気音遮断性能が低下寸ることが原因と考えられる。

・天井空気層の受音室側は密閉として, 天井空気層厚を $158 \mathrm{~mm}$ に し空気層の上部横方向に通気部を設置する場合, 天井空気層の音 圧レベルの上昇と天井 CLT パネルの振動は抑制される傾向とな り, 重量床衝撃音遮断性能は向上する。 
・さらに, 天井 CLT パネルに砂袋を設置して振動を抑制するととも に, 天井空気層厚を $196 \mathrm{~mm}$ にし, さらに空気層の上部横方向一 の通気部を 2 倍に大きくすることで, CLT パネル二重天井が無い 場合に比べて, 重量床衝撃音の L 数を最大 8 ポイント低下させる 効果がある。

CLT パネルを用いた二重天井による床衝撃音低減効果と各要因 による傾向は, 実建物においても同様に表れると推測するが, 天井 空気層の通気部を横方向へ設ける場合には同一住戸内の天井空間内 に通気させるなどの工夫が必要であり, 通気に対する抵抗の上昇の 影響なども検証していく必要があると考える。また, 本論文で提案 した CLT パネル二重天井による床衝撃音低減効果に関しては, 二重 天井の空気層厚さや CLT パネルの面密度などが变わると床衝撃音 に対する低減効果の傾向が異なることも予想される。したがって, 天井仕様のバリエーションと床衝撃音低減効果との関係性や, 低減 効果が発現する仕様の範囲・適用性などについても今後検証データ を蓄積していく必要があると考える。

\section{謝辞}

本研究の実験の一部は, 林野庁委託事業「CLT 等新たな製品・技 術の開発・普及事業（住宅等における新たな製品・技術開発事業／ CLT 住性能向上研究開発」として実施されたものです。ここに記し て関係各位に謝意を表します。

\section{参考文献}

1）平成 22 年法律第 36 号, 公共建築物等における木材利用の促進に関する法 律, 平成 22.5.26（2010.5.26）公布, 平成 22.10.1（2010.10.1）施行.

2）農林水産省告示第 3079 号, 直交集成板の日本農林規格, 平成 25.12 .20 (2013.12.20).

3）笠井祐輔, 村上剛士, 田中学, 河合誠：C L T 床版の遮音性能に関寸る実 験室測定 その 2 : 床衝撃音および空気音遮断性能の測定結果, 日本建築 学会大会学術講演梗概集, 環境工学 I, pp.155-156, 2015.9

4) 日本建築学会編: 建物床衝撃音防止設計, pp.64-66, 技報堂出版, 2009 .

5）布施幸則：実験室における二重天井の重量床衝撃音への影響, 日本建築学 会技術報告集，第 18 号, pp.149-153, 2003.12

6) 冨高隆, 野島僚子, 増田潔 : 粒状体制振天井を用いた重量床衝撃音低減に 関する検討, 日本建築学会環境系論文集，第 719 号，pp.29-39, 2016.1

7) 平光厚雄, 井上勝夫 : 乾式二重床構造の断面仕様と端部空気抜きが床衝撃 音レベル低減量に与える影響, 日本建築学会環境系論文集, 第 684 号, pp.97-102, 2013.2

8）村上剛士, 笠井祐輔, 田中学, 河合誠：C L T 床版の遮音性能に関する実 験室測定 その 1 : 実験概要および駆動点インピーダンス測定結果, 日本 建築学会大会学術講演梗概集, 環境工学 I, pp.153-154, 2015.9 


\title{
STUDY ON FLOOR IMPACT SOUND REDUCTION EFFECT BY DOUBLE CEILING SYSTEM WITH CROSS LAMINATED TIMBER PANELS
}

\author{
Manabu TANAKA*, Tsuyoshi MURAKAMI** and Yusuke KASAI** \\ * General Building Research Corporation of Japan, M. Eng. \\ ** General Building Research Corporation of Japan
}

In order to improve the floor impact sound insulation of a cross laminated timber (=CLT) floor slab, several variations of double ceiling systems with cross laminated timber panels of its thickness $90 \mathrm{~mm}$ were attached under the CLT floor slab. These floor and ceiling specimens were installed in the laboratory, and their floor impact sound levels were measured. Results of those experiments are as follows.

(1) In case of attaching a double ceiling system of CLT panels of panel thickness $90 \mathrm{~mm}$ with its air back cavity thickness $120 \mathrm{~mm}$ and closed, heavy/soft floor impact sound levels didn't increase in $63 \mathrm{~Hz}$ band. This result is different from the case of the common double ceiling system with gypsum boards. In this case, heavy/soft floor impact sound insulation performance was almost the same to that in case without a ceiling system. On the contrary, about 10dB improvement was observed in light floor impact sound insulation performance.

(2) As for the same CLT panel double ceiling system, in case of attaching a double ceiling system of CLT panels with its air back cavity opened to the sound receiving room in the lower side, air pressure increasing in the back cavity and vibration of ceiling panels were suppressed. However, both heavy/soft floor impact sound level and light floor impact sound level in the sound receiving room became higher than that of the case mentioned above with its air cavity closed. Therefore, to make the air cavity opened to the sound receiving room is quite inadequate for the purpose of floor impact sound insulation.

(3) In case of attaching a double ceiling system of CLT panels with its air back cavity (thickness $158 \mathrm{~mm}$ ) closed to the sound receiving room in the lower side but opened to horizontal direction, air pressure increasing in the back cavity and vibration of ceiling panels were suppressed. In this case, heavy/soft floor impact sound insulation performance was improved.

(4) Further, by loading weights of several sand bags on the upper surface of CLT ceiling panels with its air cavity thickness 196mm and doubling the air opening surface to the horizontal direction, heavy/soft floor impact sound level index (= L number) decreased by eight points from the case without a ceiling system. 